\title{
Pemanfaatan Ekstrak Etanol Teh Hijau (Camellia sinensis L.) sebagai Chelating Agent Logam Berat Cu dengan Metode SSA
}

\section{Utilization of Ethanol Extract of Green Tea (Camellia sinensis L.) as Chelating Agent For Heavy Metal of Cu With AAS Method}

\author{
Novena Yety Lindawati*, Riska Anggraini \\ Sekolah Tinggi Ilmu Kesehatan Nasional, Surakarta, Indonesia. \\ *E-mail:novena_yl@yahoo.com \\ Article Info: \\ Received: 10 Juli 2020 \\ in revised form: 16 Juli 2020 \\ Accepted: 28 September 2020 \\ Available Online: 30 September \\ 2020 \\ Keywords: \\ Green Tea \\ Chelating Agent \\ $\mathrm{Cu}$ Metal \\ SSA \\ Corresponding Author: \\ Novena Yety Lindawati \\ Riska Anggraini \\ Sekolah Tinggi Ilmu Kesehatan \\ Nasional \\ Surakarta \\ email: novena yl@yahoo.com

\begin{abstract}
This research was conducted to determine the ability of ethanol extract of green tea (Camellia sinensis L.) as a chelating agent for heavy metal of $\mathrm{Cu}$. Green tea extraction was carried out by maceration method using $96 \%$ ethanol solvent. The ethanol extract of green tea was further tested for phytochemical screening. Analysis of the reduction in total heavy metal content of $10 \mathrm{ppm} \mathrm{Cu}$ was measured with an Atomic Absorption Spectrophotometer (AAS) at a wavelength of $324,8 \mathrm{~nm}$. The ethanol extract of green tea (Camellia sinensis L.) was made in series of concentrations of 3 ppm, $6 \mathrm{ppm}, 12 \mathrm{ppm}$ and $15 \mathrm{ppm}$. The results showed that ethanol extract of green tea (Camellia sinensis L.) containing alkaloids, flavonoids, phenolics, tannins, saponins and triterpenoids. The average concentration value of ethanol extract of green tea in reducing $\mathrm{Cu}$ metal up to $50 \%\left(\mathrm{EC}_{50}\right)$ was
\end{abstract} \\ $12,26 \mathrm{ppm}$ with coefficient of variation $0,26 \%$.




\begin{abstract}
ABSTRAK
Penelitian ini dilakukan untuk mengetahui kemampuan ekstrak etanol teh hijau (Camellia sinensis L.) sebagai chelating agent logam berat $\mathrm{Cu}$. Ekstraksi teh hijau dilakukan dengan metode maserasi menggunakan pelarut etanol $96 \%$. Ekstrak etanol teh hijau selanjutnya diuji skrining fitokimia. Analisis penurunan kadar logam berat total $\mathrm{Cu} 10 \mathrm{ppm}$ diukur dengan alat Spektrofotometer Serapan Atom (SSA) pada panjang gelombang 324,8 nm. Ekstrak etanol teh hijau (Camellia sinensis L.) dibuat seri konsentrasi 3 ppm, 6 ppm, 12 ppm, dan 15 ppm. Hasil penelitian menunjukkan ekstrak etanol teh hijau (Camellia sinensis L.) mengandung alkaloid, flavonoid, fenolik, tanin, saponin dan triterpenoid. Nilai rata-rata konsentrasi ekstrak etanol teh hijau dalam menurunkan logam $\mathrm{Cu}$ hingga $50 \%\left(\mathrm{EC}_{50}\right)$ sebesar 12,26 ppm dengan koefisien variasi $0,26 \%$.
\end{abstract}

Kata kunci: Teh hijau; chelating agent; logam Cu; SSA.

\title{
PENDAHULUAN
}

Hati merupakan organ intestinal terbesar di dalam tubuh manusia yang berperan penting untuk mengatur metabolisme tubuh dengan tugas yang sangat kompleks dan beragam (Direktorat Bina Farmasi Komunitas dan Klinik, 2007). Fungsi hati diantaranya sebagai pengatur metabolisme kolesterol, detoksifikasi racun, tempat pembentukan protein dan asam empedu, dan tempat untuk menyimpan cadangan energi (Rosida, 2016).

Fungsi hati yang terganggu akan menimbulkan berbagai gejala penyakit dan gangguan metabolisme. Beberapa penyakit hati diantaranya adalah hepatitis, hepatitis kronis, sirosis hati, dan kanker hati (Khairiah et al., 2017). Gangguan fungsi hati dapat disebabkan oleh virus, jamur, toksisitas obat, alkohol, racun, serta toksisitas logam (Tandi, 2017; Agustina, 2014).

Salah satu logam penyebab kerusakan hati adalah tembaga $(\mathrm{Cu})$. Logam tembaga sebenarnya merupakan suatu logam essensial yang diperlukan oleh tubuh, dimana dalam kadar yang kecil dibutuhkan dalam pembentukan sel-sel eritrosit (Listiowati et al., 2011). Batas kandungan logam berat $\mathrm{Cu}$ pada air minum yang diizinkan yaitu sebesar $2 \mathrm{mg} / \mathrm{L}$ (Kuntum, 2014).

Kadar berlebih logam tembaga dalam tubuh dapat terakumulasi di dalam hati sehingga memicu terjadinya kerusakan pada sel-sel hati (Suyanto et al., 2010). Logam tembaga juga dapat menimbulkan efek toksik ditandai dengan terjadinya penyakit Wilson dengan gejala terjadi sirosis hati, gangguan sel-sel otak, demielinasi, kinerja ginjal menurun, dan adanya logam tembaga yang mengendap pada kornea mata, serta penyakit Kinsky yang ditandai dengan rambut penderita menjadi kaku dan warnanya menjadi kemerahan (Listiowati et al., 2011).

Teh hijau telah diketahui mengandung senyawa flavonoid yang dapat mengikat logam berat (Hernayanti et al., 2019). Berdasarkan penelitian yang dilakukan Anggraini et al., (2014) pemberian air teh hijau dapat menurunkan konsentrasi ion $\mathrm{Pb}$ (II) dimana hasil optimum terjadi pada pemberian air teh hijau dengan waktu kontak 10 menit dan volume air teh $650 \mathrm{~mL}$.

Kemampuan chelating agent ekstrak etanol teh hijau terhadap logam berat $\mathrm{Cu}$ dengan metode SSA bertujuan untuk menambahkan pemanfaatan bahan alam yang dapat digunakan sebagai hepatoprotektor organ hati akibat logam berat $\mathrm{Cu}$.

\section{METODE PENELITIAN}

\section{Alat dan Bahan}

Peralatan yang digunakan yaitu Spektrofotometer serapan atom (Thermo Scientific ${ }^{\circledR}$ iCE 3000 Series), beaker glass $\left(\right.$ Iwaki $\left.^{\circledR}\right)$, neraca analitik (Ohaus, EP214), labu ukur (Pyrex ${ }^{\circledR}$ ), penangas air, rotary evaporator $\left(\mathrm{IKA}^{\circledR}\right)$, corong kaca $\left(\mathrm{Herma}^{\circledR}\right)$, corong pisah, cawan porselin, bejana maserasi, ayakan 60 
Mesh, gelas ukur (Iwaki $\left.{ }^{\circledR}\right)$, pipet volume $\left(\right.$ Pyrex $\left.^{\circledR}\right)$, blender, pengaduk magnet. Bahan-bahan yang digunakan adalah simplisia teh hijau, serbuk $\mathrm{CuSO}_{4} .5 \mathrm{H}_{2} \mathrm{O}$ (MERCK ${ }^{\circledR}$, grade $\mathrm{Ph}$ Eur, BP, USP), etanol 96\% $\left(\right.$ Medika $^{\circledR}$ ), aquabidest $\left(\right.$ Pharmindo $^{\circledR}$ ), kloroform pro analisis (Emsure ${ }^{\circledR}$, gradien grate $\geq 99,7 \%$ ), $\mathrm{NaOH} 1 \mathrm{~N}\left(\mathrm{MERCK}^{\circledR}\right)$, ditizon 0,005\% b/v $\left(\right.$ MERCK $\left.^{\circledR}\right)$, gelatin 0,5\%, pereaksi skrining fitokimia.

\section{Metode}

\section{Determinasi Tanaman}

Tanaman teh hijau telah dideterminasi di B2P2TOOT Kecamatan Tawangmangu, Kabupaten Karanganyar, Jawa Tengah dengan no YK.01.03/2/3653/2019.

\section{Preparasi Sampel}

Bahan berupa simplisa teh hijau dilakukan sortasi kering, selanjutnya dihaluskan menjadi serbuk dengan menggunakan blender dan diayak dengan ayakan 60 Mesh.

\section{Pembuatan Ekstrak Etanol Teh Hijau}

Serbuk kering teh hijau sebanyak 100 gram dimasukkan ke dalam gelas bejana tertutup, kemudian ditambahkan etanol $96 \%$ sebanyak $750 \mathrm{~mL}$ dan dilakukan perendaman selama 5 hari $(5 \times 24$ jam) serta dilakukan pengadukan setiap harinya, setelah 5 hari dilakukan penyaringan menggunakan kain flanel. Filtrat yang diperoleh selanjutnya ditampung dan ampasnya di maserasi kembali dengan pelarut yang sama sebanyak $250 \mathrm{~mL}$ selama 2 hari $(2 \times 24$ jam). Filtrat yang diperoleh dicampur menjadi satu dan dipekatkan dengan rotary evaporator pada suhu $50{ }^{\circ} \mathrm{C}$, kemudian dilanjutkan dengan waterbath pada suhu yang sama hingga diperoleh ekstrak kental. Pembuatan ekstrak direplikasi sebanyak 3 kali.

\section{Uji Skrining Fitokimia}

Ekstrak etanol teh hijau yang diperoleh selanjutnya diuji kandungan fitokimianya meliputi uji alkaloid, flavonoid, fenolik, tanin, saponin, dan triterpenoid.

\section{Uji Kualitatif dan Kuantitatif Logam Cu dalam Sampel}

Sebanyak $5 \mathrm{~mL}$ ekstrak etanol teh hijau ditambahkan dengan larutan $\mathrm{NaOH} 1 \mathrm{~N}$ sampai diperoleh kondisi $\mathrm{pH} 3,5$, selanjutnya dalam larutan tersebut ditambahkan larutan ditizon 0,005\% b/v sebanyak 5 $\mathrm{mL}$ kemudian digojog hingga terjadi perubahan warna, jika larutan berwarna ungu maka sampel positif mengandung logam $\mathrm{Cu}$ (Setyaningsih et al., 2012). Ekstrak etanol teh hijau dengan seri konsentrasi berbeda dianalisa secara kuantitatif dengan alat SSA dengan panjang gelombang 324,8 nm.

\section{Pembuatan Larutan Baku Tembaga}

Pembuatan Larutan Baku Induk Tembaga 1000 ppm; 100,0 mL

Serbuk $\mathrm{CuSO}_{4} .5 \mathrm{H}_{2} \mathrm{O}$ ditimbang sebanyak 0,3929 gram, selanjutnya dilarutkan menggunakan aquabidest secukupnya serta dimasukkan dalam labu ukur 100,0 mL, selanjutnya ditambah aquabidest hingga tanda batas dan dihomogenkan. 
Pembuatan Limbah Simulasi Cu 10 ppm; 100,0 mL

Larutan baku induk $\mathrm{Cu} 1000$ ppm dipipet sebanyak 1,0 mL dan dimasukkan ke labu ukur 100,0 mL, selanjutnya ditambah aquabidest hingga tanda batas dan dihomogenkan. Larutan limbah simulasi $\mathrm{Cu}$ dibaca kadarnya pada alat SSA dengan panjang gelombang 324,8 nm.

\section{Uji chelating agent ekstrak etanol teh hijau terhadap logam berat $\mathrm{Cu}$}

Ekstrak etanol teh hijau 3 ppm, 6 ppm, 12 ppm, dan 15 ppm dalam labu ukur 100,0 mL selanjutnya direaksikan dengan baku induk tembaga konsentrasi $1000 \mathrm{ppm}$ sebanyak $1 \mathrm{~mL}$ serta ditambahkan aquabidest hingga tanda batas (konsentrasi larutan limbah simulasi sebesar $10 \mathrm{ppm}$ pada masingmasing konsentrasi). Larutan tersebut kemudian diaduk dengan stirer magnetik selama 30 menit, selanjutnya dimasukkan kedalam corong pisah serta ditambahkan $10 \mathrm{~mL}$ kloroform, kemudian digojog selama 10 menit. Larutan tersebut selanjutnya didiamkan hingga terbentuk dua fase yang terpisah yaitu fase air dan fase kloroform. Fase air dipisahkan, ekstraksi diulangi sebanyak 3 kali. Fase air yang diperoleh selanjutnya dianalisis dengan alat SSA untuk mengetahui kadari $\mathrm{Cu}$ sisa dalam larutan.

\section{Analisa Data}

Pengukuran penurunan kadar logam berat $\mathrm{Cu}$ dilakukan dengan alat SSA dengan panjang gelombang $\mathrm{Cu} 324,8 \mathrm{~nm}$ (Listiowati et al., 2011). Persen penurunan kadar logam berat tembaga (Cu) diperoleh dengan menggunakan rumus :

$$
\% \text { Penurunan }=\frac{(\text { kadar } \mathrm{Cu} \text { awal }- \text { kadar } \mathrm{Cu} \text { akhir })}{\text { kadar } \mathrm{Cu} \text { awal }} \times 100 \%
$$

Perhitungan nilai $\mathrm{EC}_{50}$ merupakan konsentrasi suatu metabolit yang memiliki kemampuan dalam menurunkan kadar logam Cu sebanyak 50\% dari kadar total logam awal. Nilai $\mathrm{EC}_{50}$ diperoleh dari data hubungan konsentrasi ekstrak etanol teh hijau (X) dengan efektivitas penurunan ekstrak tersebut terhadap logam berat $\mathrm{Cu}(\mathrm{Y})$ yang dinyatakan dalam persamaan garis regresi sebagai berikut:

$$
\mathrm{Y}=\mathrm{BX}+\mathrm{A}
$$

$$
\text { Keterangan : } \begin{aligned}
\mathrm{Y} & =\text { persen }(\%) \text { efektivitas } \\
\mathrm{X} & =\text { konsentrasi sampel } \\
\mathrm{B} & =\text { kemiringan kurva (slope) } \\
\mathrm{A} & =\text { intersep }
\end{aligned}
$$

Presisi diperoleh dari data rata-rata $\mathrm{EC}_{50}$ kadar sampel yang masing-masing dilakukan 3 kali replikasi $(\mathrm{n}=3)$. Persen presisi dapat dilihat dari nilai koefisien variasi $(\% \mathrm{KV})$. Semakin kecil nilai \%KV, artinya data yang diperoleh semakin baik. Nilai $\% \mathrm{KV}$ dinyatakan baik jika $\leq 2 \%$ (Harmita, 2004). Koefisien variasi dirumuskan sebagai berikut:

$$
\% \mathrm{KV}=(\mathrm{SD} / \text { rata-rata }) \times 100 \%
$$

$\begin{aligned} \text { Keterangan }: \% \mathrm{KV} & =\text { Koefisien variasi } \\ \mathrm{SD} & =\text { Standar deviasi }\end{aligned}$ 


\section{HASIL DAN PEMBAHASAN}

Hasil determinasi menunjukkan bahwa tanaman teh hijau yang berasal dari Kemuning, Karanganyar yang digunakan sebagai simplisia dalam penelitian merupakan tanaman teh hijau dengan spesies Camellia sinensis (L.) Kuntze dan termasuk dalam familia Theaceae.

Simplisia teh hijau dihaluskan hingga menjadi serbuk dengan tujuan untuk untuk memperkecil ukuran sampel dan meningkatkan luas permukaannya, sehingga kontak antara sampel dengan pelarut semakin luas, dengan demikian memungkinkan komponen zat aktif yang terdapat dalam teh hijau dapat diekstrak secara maksimal. Serbuk simplisia diayak dengan ayakan 60 Mesh. Penggunaan ayakan 60 Mesh didasarkan pada penelitian yang dilakukan Wartini et al.,., (2017) mengenai pengaruh kehalusan terhadap mutu ekstrak Sargassum polycystum menunjukkan bahwa rendemen tertinggi didapatkan pada ukuran partikel bubuk 60 Mesh.

Serbuk simplisa teh hijau diekstraksi menggunakan cara maserasi dengan melakukan proses perendaman. Maserasi dipilih karena prosesnya yang sederhana, tidak memerlukan peralatan yang rumit, relatif murah, dan tidak melibatkan pemanasan sehingga dapat menghindari kerusakan senyawa kimia yang tidak tahan terhadap pemanasan. Hasil dari proses maserasi didapatkan rendemen ekstrak etanol teh hijau pada replikasi 1 sebanyak 39,3\% b/b, replikasi 2 sebanyak 32,7\% b/b, dan replikasi 3 sebanyak $32,1 \% \mathrm{~b} / \mathrm{b}$.

Kandungan senyawa dalam ekstrak etanol teh hijau dapat dipastikan dengan uji skrining fitokimia. Salah satu senyawa yang dapat berperan sebagai chelating agent logam berat $\mathrm{Cu}$ adalah flavonoid. Senyawa flavonoid diduga dapat berfungsi sebagai agen pengkhelat logam karena terdapat atom yang memiliki pasangan elektron bebas yaitu atom oksigen, sehingga dapat berikatan dengan logam berat (Fitri et al., 2019).

Tabel 1. Hasil pengujian skrining fitokimia ekstrak etanol teh hijau

\begin{tabular}{|c|c|c|c|c|}
\hline Uji Senyawa & Reagen & Teoritis & Hasil & Keterangan \\
\hline Alkaloid & $\begin{array}{c}\mathrm{H}_{2} \mathrm{SO}_{4} 2 \mathrm{~N}, \\
\text { Mayer } \\
\text { Wagner } \\
\text { Dragendroff }\end{array}$ & $\begin{array}{l}\text { Endapan putih } \\
\text { Endapan cokelat } \\
\text { Endapan jingga }\end{array}$ & $\begin{array}{l}\text { Endapan putih } \\
\text { Endapan cokelat } \\
\text { Endapan jingga }\end{array}$ & $\begin{array}{l}(+) \\
(+) \\
(+)\end{array}$ \\
\hline Flavonoid & $\begin{array}{l}\text { Serbuk Mg, } \\
\mathrm{HCl} \text { pekat }\end{array}$ & $\begin{array}{c}\text { Merah, kuning atau } \\
\text { jingga }\end{array}$ & Jingga & $(+)$ \\
\hline Fenolik & $\mathrm{FeCl}_{3} 1 \%$ & $\begin{array}{l}\text { Hitam kebiruan } \\
\text { atau hijau }\end{array}$ & $\begin{array}{c}\text { Hitam } \\
\text { kebiruan }\end{array}$ & $(+)$ \\
\hline Tanin & Gelatin $0,5 \%$ & Endapan cokelat & $\begin{array}{c}\text { Endapan } \\
\text { cokelat }\end{array}$ & $(+)$ \\
\hline Saponin & Aquadest & Buih & Buih & $(+)$ \\
\hline Triterpenoid & $\begin{array}{l}\mathrm{CH}_{3} \mathrm{COOH}, \\
\mathrm{H}_{2} \mathrm{SO}_{4} \text { pekat }\end{array}$ & $\begin{array}{c}\text { Merah jingga atau } \\
\text { ungu }\end{array}$ & Merah jingga & $(+)$ \\
\hline
\end{tabular}

Keterangan: $(+)=$ positif

Hasil skrining fitokimia menunjukkan bahwa ekstrak etanol teh hijau mengandung senyawa alkaloid, flavonoid, fenolik, tanin, saponin, dan triterpenoid (Tabel 1). Hal tersebut telah sesuai dengan 
penelitian yang dilakukan oleh Setiyono \& Budi, (2014) tentang skrining fitokimia terhadap enam genotipe teh.

Kandungan logam berat $\mathrm{Cu}$ dalam ekstrak etanol teh hijau dapat diketahui dengan dilakukan uji kualitatif logam $\mathrm{Cu}$. Reaksi larutan ditizon dengan logam $\mathrm{Cu}$ akan membentuk kompleks logam ditizonat yang spesifik. Reaksi yang terjadi adalah sebagai berikut :

$$
\mathrm{Cu}^{2+}+2 \mathrm{HDz} \longrightarrow \mathrm{Cu}(\mathrm{HDz})_{2}+2 \mathrm{H}^{+}
$$

Hasil uji keberadaan logam berat $\mathrm{Cu}$ dalam ekstrak etanol teh hijau menunjukkan warna jingga, hal ini membuktikan bahwa ekstrak etanol teh hijau negatif mengandung logam $\mathrm{Cu}$.

Keberadaan logam $\mathrm{Cu}$ dalam ekstrak etanol teh hijau secara kuantitatif dipastikan kembali dengan melakukan uji kuantitatif menggunakan alat SSA. Hasil uji kuantitatif mendukung hasil uji kualitatif yaitu menunjukkan hasil yang negatif atau dapat dikatakan ekstrak etanol teh hijau yang digunakan tidak mengandung logam $\mathrm{Cu}$, sehingga tidak menganggu proses penelitian.

Ekstrak etanol teh hijau dalam beberapa seri konsentrasi dicampurkan dengan logam $\mathrm{Cu}$ dengan kadar $10 \mathrm{ppm}$. Campuran tersebut kemudian dihomogenkan dengan alat stirer magnetik selama 30 menit dengan tujuan agar senyawa flavonoid yang terdapat pada ekstrak etanol teh hijau dapat berikatan dengan $\mathrm{Cu}^{2+}$.

Proses pemisahan kompleks dengan sisa logam $\mathrm{Cu}$ dilakukan melalui metode ekstraksi. Ekstraksi dilakukan menggunakan pelarut organik kloroform sebanyak $10 \mathrm{ml}$ dengan campuran larutan yang mengandung logam $\mathrm{Cu} 10 \mathrm{ppm}$ dan ekstrak etanol teh hijau dalam beberapa seri konsentrasi, dimana pada setiap konsentrasi dilakukan ekstraksi sebanyak 3 kali dan digojog selama 10 menit untuk memaksimalkan proses pemisahan kompleks dengan sisa logam $\mathrm{Cu}$. Pemilihan kloroform sebagai pelarut organik dalam proses ekstraksi dikarenakan pelarut tersebut mempunyai sifat non polar dan tidak bercampur dengan air, sehinga akan terbentuk dua fase yang terpisah yaitu fase kloroform dan fase air. Sifat non polar tersebut akan sangat berpengaruh terhadap kemudahan kompleks yang terbentuk terdistribusi ke fase kloroform, sedangkan sifatnya yang tidak bercampur dengan air akan memudahkan dalam proses pemisahan kompleks tersebut dari campurannya dalam fase air (Anggraini et al., 2014). Fase air yang diperoleh dilakukan pengujian dengan alat SSA dengan panjang gelombang 324,8 nm untuk mengetahui efektivitas penurunan konsentrasi logam berat $\mathrm{Cu}$ setelah ditambahkan ekstrak etanol teh hijau dalam beberapa seri konsentrasi.

Tabel 2. Hasil penurunan kadar Cu tiap konsentrasi

\begin{tabular}{|c|c|c|c|c|c|c|}
\hline \multirow{2}{*}{$\begin{array}{c}\text { Ekstrak } \\
\text { etanol teh } \\
\text { hijau }\end{array}$} & \multicolumn{4}{|c|}{ Konsentrasi (\%) } & \multirow{2}{*}{ Persamaan regresi } & \multirow{2}{*}{$\begin{array}{r}\mathrm{EC}_{50} \\
(\mathrm{ppm})\end{array}$} \\
\hline & $3 \mathrm{ppm}$ & $6 \mathrm{ppm}$ & $12 \mathrm{ppm}$ & $15 \mathrm{ppm}$ & & \\
\hline 1 & 7,01 & 23,63 & 46,36 & 63,84 & $y=4,5463 x-5,7070$ & 12,25 \\
\hline 2 & 7,83 & 22,77 & 47,45 & 63,30 & $y=4,5207 x-5,3485$ & 12,24 \\
\hline 3 & 8,65 & 21,68 & 47,72 & 62,84 & $y=4,4807 x-5,1035$ & 12,30 \\
\hline \multicolumn{6}{|c|}{$\begin{array}{c}\text { Nilai Rata-rata } \mathrm{EC}_{50} \\
\text { KV }\end{array}$} & $\begin{array}{r}12,26 \\
0,26 \% \\
\end{array}$ \\
\hline
\end{tabular}

Hasil penelitian menunjukkan bahwa ekstrak etanol teh hijau mempunyai kemampuan dalam mengikat kadar logam $\mathrm{Cu}$ (Tabel 2), dimana dengan adanya peninkatan konsentrasi ekstrak etanol teh hijau maka akan semakin besar penurunan kadar logam $\mathrm{Cu}$. Hal ini berarti senyawa organik yang terdapat dalam ekstrak etanol teh hijau dapat mengikat logam $\mathrm{Cu}$. Rata-rata nilai $\mathrm{EC}_{50}$ yang diperoleh adalah sebesar 12,26 ppm. 
Ekstrak etanol teh hijau diketahui memiliki kandungan senyawa flavonoid yang diduga dapat berfungsi sebagai agen pengkhelat logam berat (Hernayanti et al., 2019). Penurunan konsentrasi logam $\mathrm{Cu}$ dapat terjadi karena flavonoid yang terdapat dalam teh hijau berikatan dengan logam $\mathrm{Cu}$. Semakin meningkatnya konsentrasi ekstrak etanol teh hijau yang diberikan, persen penurunan kadar logam $\mathrm{Cu}$ juga semakin meningkat.

Kenaikan konsentrasi pemberian ekstrak etanol teh hijau dalam larutan menunjukkan bahwa jumlah flavonoid yang ada dalam sistem reaksi semakin banyak. Semakin banyak jumlah molekul flavonoid, maka semakin banyak pula elektron-elektron yang akan berikatan dengan logam $\mathrm{Cu}$, sehingga penurunan konsentrasi logam $\mathrm{Cu}$ menjadi lebih efektif.

Teh hijau mengandung senyawa polifenol meliputi flavanol, flavonoid, flavandiol, dan asam fenolik dimana keseluruhan jumlahnya dapat mencapai 30\% dari berat teh kering (Chacko et al., 2010). Kemampuan flavonoid sebagai pengkhelat didasarkan pada kemampuannya untuk mengkompleks logam yaitu dengan keberadaan pasangan elektron bebas pada salah satu atom dalam flavonoid sehingga dapat berikatan dengan atom pusat yaitu logam (Fitri et al., 2019).

Presisi atau ketelitian dalam penelitian dapat dilihat dari nilai KV pada tabel 2. Nilai KV dinyatakan baik jika nilainya $\leq 2 \%$ (Harmita, 2004). Nilai KV yang diperoleh dari replikasi 1, replikasi 2, dan replikasi 3 yaitu sebesar $0,26 \%$, yang menunjukkan bahwa nilai KV kurang dari $2 \%$, artinya proses pengerjaan yang dilakukan memiliki tingkat ketelitian yang baik.

\section{KESIMPULAN}

Ekstrak etanol 96\% teh hijau (Camellia sinensis L.) dapat menurunkan kadar logam berat $\mathrm{Cu}$ dengan $\mathrm{EC}_{50}$ sebesar 12,26 ppm dan nilai KV sebesar 0,26\%.

\section{DAFTAR PUSTAKA}

Agustina, Titin. (2014). Kontaminasi Logam Berat pada Makanan dan Dampaknya Pada Kesehatan. Teknobuga, 1(1), 53-65.

Anggraini, D.I., Sukirno., Wulansari, A.D. (2014). Antidotum Logam Timbal (Pb) Secara In Vitro dengan Seduhan Air Teh Hijau. Jurnal Ilmiah Kesehatan, 6(2), 105-108.

Chacko, S.M., Thambi, P.T., Kuttan, R., dan Nishigaki. (2010). Benefical Effects of Green Tea : A Literature Review. Chinese Medicine, 5(13), 1-9.

Direktorat Bina Farmasi Komunitas dan Klinik. (2007). Pharmaceutical Care untuk Hati. Departemen Kesehatan RI.

Fitri, D.S., Widiyantoro, A., Gusrizal. (2019). Potensi Fraksi Etil Asetat dari Buah Mangga (Mangifera spp.) sebagai pengompleks logam Pb (II) dan Isolasi Senyawa Flavonoidnya. Jurnal Kimia Khatulistiwa, 8(1), 65-70.

Harmita. (2004). Petunjuk Pelaksanaan Validasi Metode dan Cara Perhitungannya. Majalah Ilmu Kefarmasian, 1(3), $117-135$.

Hernayanti., Moeljopawiro, S., Sadewa, A.H., Sasongko, N.D., Hidayah, H.A. (2019). Katekin dalam Teh Hijau sebagai Kelator Alami pada Individu Terpapar Plumbum Pembawa Polimorfisme Gena Nitrit Oksida Sintase 3. Majalah Ilmiah Biologi Biosfera : A Scientific Journal, 36(2), 90 -98 . 
Khairiah, L., Tursina., Rismawan, T. (2017). Sistem Pakar Diagnosis Penyakit Hati dengan Metode Dempster Shafer Berbasis Android. Jurnal Coding Sistem Komputer Untan, 5(2), 57-66.

Kuntum, K. (2014). Analisis Kadar Tembaga (Cu) dan Seng (Zn) dalam Air Minum Isi Ulang Kemasan Galon di Kecamatan Lima Kaum Kabupaten Tanah Datar. Jurnal Sainstek, 6(2), 116123.

Listiowati., Rahayu, W.S., Utami, P.I. (2011). Analisis Cemaran Tembaga dalam Air Sumur Industri Pelapisan Emas di Kota Tegal dengan Metode Spektrofotometri Serapan Atom. Pharmacy, 8(3), 71-79.

Rosida, A. (2016). Pemeriksaan Laboratorium Penyakit Hati. Berkala Kedokteran, 12(1), 123-131.

Setiyono, R.T., dan Budi, M. (2014). Skrining Fitokimia Enam Genotipe Teh. Jurnal TIDP, 1(2), 6368.

Setyaningsih, E., Saputro, A., dan Hariyatmi. (2012). Identifikasi Kualitatif Kandungan Logam Berat $(\mathrm{Pb}, \mathrm{Cd}, \mathrm{Cu}$, dan $\mathrm{Zn}$ ) pada Ikan Sapu-Sapu (Hypostomus plecostomus) di Sungai Pabelan Kartasura tahun 2012. Seminar Nasional IX Pendidikan Biologi FKIP UNS, Surakarta.

Suyanto, A., Kusmiyati, S., Ch, Retnaningsih. (2010). Residu Logam Berat Ikan dari Perairan Tercemar di Pantai Utara Jawa Tengah. Jurnal Pangan dan Gizi, 1(2), 33-38.

Tandi, J. (2017). Pola Penggunaan Obat pada Pasien Penyakit Hati yang Menjalani Rawat Inap di Rumah Sakit Umum Daerah Undata Palu. Jurnal Pengembangan Sumber Daya Insani, 2(2), 218-233.

Wartini, N.M., Noviantari, N.P., Suhendra, L. (2017). Pengaruh Ukuran Partikel Bubuk Dan Konsentrasi Pelarut Aseton Terhadap Karakteristik Ekstrak Warna Sargassum polycystum. Jurnal Rekayasa dan Manajemen Agroindustri, 5(3), 102-112. 